\title{
Export Compliance: A Missing Component of International Entrepreneurship
}

\author{
Vahid Jafari Sadeghi ${ }^{1}$, Paolo Pietro Biancone ${ }^{1}$, Charles Giacoma ${ }^{2} \&$ Silvana Secinaro ${ }^{1}$ \\ ${ }^{1}$ Department of Management, University of Turin, Turin, Italy \\ ${ }^{2}$ European Institute for Export Compliance, Turin, Italy \\ Correspondence: Vahid Jafari Sadeghi, Department of Management, University of Turin, Turin, Corso Unione \\ Sovietica 218 bis 10134, Italy. Tel: 39-011-670-6280. E-mail: Vahid.Jafari.Sadeghi@unito.it
}

Received: August 22, 2017

doi:10.5539/ijbm.v12n11p103
Accepted: September 22, $2017 \quad$ Online Published: October 18, 2017

URL: https://doi.org/10.5539/ijbm.v12n11p103

\begin{abstract}
There is a consensus that firm's corporate governance impacts their ability to export. Corporate governance relies on export compliance as a framework which supports enterprises in order to mitigate their risks associated with export and provides a safe platform for firms to upgrade their position in the world of trade. The aim of this paper is to widen concepts of export control and compliance framework. The paper outlines the general structure of export compliance and presents a comprehensive view of United States of America and the European Union as powers in the world. In this study, we explained the nature of the violations from the point of view of export compliance and reached to dual-use, money laundering violation and sanctions embargos or restrictive measures. The methodology of this study is documenting analysis with an inductive approach. Essential data for this study has been gathered from secondary resources including diverse scientific research articles, institutional guidance notes, guidelines, manuals and export compliance related web sites and legal provisions in legislations of different countries.
\end{abstract}

Keywords: SME, export compliance, risk, dual-use, money laundering, sanctions embargos

\section{Introduction}

Internationalization is one of the most complexes, but increasingly necessary strategies can be undertaken by enterprises (Fernández \& Nieto 2005; Jafari Sadeghi \& Biancone 2017). While, in recent years, development of technologies and reduction of barriers across borders through regional trade agreements have facilitated the market globalization (Zou \& Stan 1998; Leonidou, 2004; Maignan \& Lukas, 1997), accelerating changes in the international business environment still made the global markets hard to enter (Dana \& Wright, 2009; Acs, Dana, \& Jones 2003; Etemad, Wright, \& Dana 2001; Jafari Sadeghi, Jashnsaz, \& Honari Chobar, 2014). However, the global market has been faced with a rising trend in internationalization among firms in the last twenty years (OECD, 2008).

However, expanding the international activities is crucial for firms, especially small and medium-sized enterprises (SMEs), to survive, succeed and growth (Majocchi, Bacchiocchi, \& Mayrhofer 2005; Dikova et al., 2016) and promote their economic growth. Moreover, SMEs need to get along with various exporting challenges, depending on that from which country SME operates. SMEs belongs to transitional economies mainly meet internal derived challenges like unprincipled and unskillful behavior or lack of capital (Khattak, Arslan, \& Umair, 2011) whereas firms from developed economies generally confront external problems like or import restriction policies or political instability (Neupert, Baughn, \& Dao, 2006).

In last decade, one emerging issue for ventures desire to sell their products and services abroad is their commitment to avoid making conflict in international level. In fact, firms have to comply with the international regulations to prevent violations which make the world unsafe. However, exporting firms no matter of their size, whether large and multinational firms or SMEs, may directly or indirectly face with the export compliance violations. The western governments for increasing their national security rely on the due diligence of exporters. However, there is an increasing concern linked to security, whether international or homeland, as well as terrorism and the proliferation of mass destructive weapons. Therefore, there should be a strong partnership between the public and private sector that prevent any diversion of dual-use items for devastating and harmful 
purposes (BIS, 2011). In this case, making a balance between national security, from one perspective, and commercial and efficiency interests, from the other perspective, is an essential issue for firms to consider which can be applied by promoting innovation while minimizing risks (Samson, 2015).

However, United States conducted export regulations that restricted sharing the types of knowledge to foreign parties and have strict guidelines on the types of knowledge that cannot be shared with non-US citizens and carry heavy penalties for non-compliance that fall equally on the organization in question and its executives who should have known better (Avellanet, 2008). In this vein, dual-use items defined to items that not only have a commercial application but also can be used for terrorism, military or mass destruction weapons (Biancone \& Jafari Sadeghi, 2016). Considering the extensive variety of commodities that may be so categorized and also the function each party in a transaction, enterprises in all sectors have to adopt an export compliance program, and this program/ solution herein may be adapted to all exporting industries or to ones have a plan to export. Non-compliance with US regulations and laws may cause to the imposition of civil or/ and criminal penalties and fines (Fusco, 2015).

The methodology of this study is documenting analysis with an inductive approach. Essential data for this study has been gathered from secondary resources including diverse scientific research articles, institutional guidance notes, guidelines, manuals and export compliance related web sites and legal provisions in legislations of different countries.

At first, we seek to present export compliance's concepts and definitions. Two views of export control and compliance, United States of America's view and European Union's view, will be assessed. Then, in order to manage risks associated with export compliance, a framework will be built. Secondary data have a great role in this part.

\section{Export Compliance}

According to EIFEC (2017), export compliance is defined as a multidisciplinary and specialized framework, which supports enterprises in compliance risk management, like the risk of reputation deterioration administrative or administrative sanctions or financial losses for non-compliance with rules, regulations, laws, and legislation, codes of conduct and good practice. It includes all international activities of organizations including export and import of any kind of commodities and/ or services, whether intangible or intangible assets (also the money transfer or payment) which somehow are subject to restrictive regulations (Dual Use, Sanctions and restrictive measures etc.) enforceable to arrangement between two different jurisdictions/ states/ entities (EIFEC, 2017). The term organizations are intended as all public and private organizations that have activities falling within the scope of this charter including companies of any nature, associations and even bodies. The term export also refers to the international activity of organization; an import in a broader sense, as an indissoluble operation (EIFEC, 2017).

However, depending on the size and the nature of the firm, compliance programs might vary. For instance, some firms decide to appoint a single expert responsible for compliance endeavors as well as administration, performance, and coordination of export. Other kinds of organizations prefer to decentralize these authorities to a number of employees throughout the organization and supervise these responsibilities to make sure if essential compliance standards are maintained. To avoid of failing to comply with export regulations the size and organizational structure, and production/ distribution network of an organization act as the crucial determinants of where personnel and compliance functions should reside. Many enterprises amalgamate the administration of recordkeeping, training, dissemination of regulatory material, the alarm of failure to comply, and audits. However, wherever firsthand knowledge and information of customers is available, the actual screening efforts against different governmental restrictions of foreign individuals that ought to be avoided, known and tracked end-use and end-user activities, and violation risk may be carried out by personnel throughout the organization like in sales and marketing, order entry, or shipping (BIS, 2011).

Altogether, for most of the international activities, any specific approval from the US government is not required. However, In order to make some certain global transactions legally, exporters need to take, in advance, a special export permission which is called a license. In fact, licenses are needed for specific situations concerning foreign policy, nuclear nonproliferation, regional stability, national security, missile technology, short supply, biological and chemical weapons, and crime control or terrorist concerns. (BIS, 2011).

There are essential regulations in the export compliance process that organization needs to comply with them:

\subsection{International Traffic in Arms Regulations (ITAR)}

ITAR is a group of export control regulations that were adopted under the Arms Export Control Act. AECA 
allows the government to control the export of defense items, services, and technical data to other nations, and ITAR is the implementation of these controls. The policy behind ITAR is to further "world peace and security" (Blount, 2007). In order to control the spread of capacities and military technology to specific nations or groups, firms that produce, manufacture and export defense items, services and technologies need to comply with certain export regulations. Thus, exporting enterprises are responsible for compliance with the ITAR governing export regulations which are issued by the US Department of State (DOS) and administered by the Office of Defense Trade Controls. Therefore, organizations or individuals who deviate or violate ITAR export regulations are exposed to the extensive civil and criminal penalties (IIEI, 2016). In this regard, a violation of the ITAR's export restrictions is when any individual or organization willfully exports, or attempts to export, an item contained in the United States Munitions List without a license (Masero, 2014).

\subsection{Export Administration Regulations (EAR)}

EAR regulations include dual-use services, items or even technologies that not only have commercial applications but also can be applied in manufacture or development of mass destruction or conventional weapons (Saunders 1999). EAR restrictions are performed by the US Department of Commerce (DOC) and administered by the Bureau of Industry and Security (BIS) and maintain control over all US commodities around the world, and all goods in the US, regardless of where produced (IIEI, 2016). Moreover, many items that do not require a license under ITAR need to be controlled by EAR.

\subsection{Office of Foreign Assets Control Regulations (OFAC)}

In Department of Treasury (DOT), the office of foreign assets control administers and performs trade and economic sanctions against international narcotics, terrorism sponsoring organizations, and targeted foreign countries (IIEI 2016). The OFAC also administered numerous economic sanctions and other trade bans against the Balkans, Cuba, Iran, Iraq, Liberia, Myanmar, North Korea, Russia, Sudan, Syria, and Zimbabwe. In the other hand, the OFAC also performs and promulgates regulations concerning terrorism and weapons of mass destruction proliferation, diamond trading, narcotics trafficking regardless of which country is implicated (Troxel, 2005).

However, there other rules and regulations regarding export compliance and exports from/ to the US may be subject to regulations administered other government agencies, in addition to ITAR and EAR. Department of Energy (DOE) regulates natural gas, electric power, and nuclear technology. The Defense Threat Reduction Agency in Department of Defense (DOD) formulates strategies on international transfers of defense-related technology and reviews certain dual-use export license applications referred by the DOC. Drug Enforcement Administration (DEA) controls the export and import of listed chemicals material used for the production of commodities under the Controlled Substances Act. The US Environmental Protection Agency's (EPA) Office of Solid Waste regulates toxic waste exports. The US Food and Drug Administration (FDA) licenses drugs and medical devices. Nuclear Regulatory Commission (NRC) licenses nuclear materials and equipment, and the US Patent and Trademark Office (USPTO) administers to patent filing data sent abroad (IIEI, 2016).

In the internationally integrated world of business, effective export compliance is only practicable with cooperation at a European and international level. The EU economies count on the due compliance of exporters to make sure that all laws are respected (EIFEC, 2017). In Europe, EIFEC by promoting and managing the EU Export Compliance Framework (EU-ECF) has a mission to develop the international security. In fact, the EU-ECF framework gives innovative solutions to the most critical challenges in a global marketplace and supports the organization's business targets, recognizes the boundaries of ethical and legal behavior, and sets up a system to alert management when the organization is getting close to a boundary, crossing it or approaching a challenge that creates problem on the achievement of a business goals.

\section{How to Control the Risk of Export Compliance Violation}

In business and commercial literature, the risk is defined as an uncertain condition which may consequence to losing something of value and finally negatively influence the organizations' objectives (Ojasalo, 2009). The term of export refers to the goods/ services that an enterprise supplies to customers abroad. Thus, export risks are conceived as determinants which, with a certain degree of probability, adversely impact the success of an organization in international markets (Lehmann et al., 2013). In this vein, risk management has a crucial role in companies success in global business (Thun \& Hoenig, 2011).

In the macro level, due to increase the economic growth, governments with different economic characteristics around the world try to improve performance of the SMEs in international markets while, in micro level, however, being successful and respected in the local market will not necessarily leads enterprises to become 
successful also in the export market, too. (Zehir, Köle, \& Yıldız, 2015). For this reason, we build a framework which outlines SMEs in order to comply with risks related to export compliance. First, the beneficiaries are specified. Next, we explain violations which are reasons of putting the organization in sanction and punishments list. Finally, with regard the history, proportionate sanctions on each kind of risks are presented. However, beneficiaries of this framework are including all organizations, companies, and associations under the definition of SME that are active in international trade or want to do import and export activities.

In the context of undertaking international trade, firms who are exporting or who are planning to export are subject to risks to comply with the regulation in terms of exporting. International trade is affected by, but not limited to, a range of violations about export compliance which failure to comply with them may cause sanction for the organization.

\subsection{Dual-use item}

Dual use technologies are those that have both civilian and military use (Saunders, 1999; Orr \& Lee, 2009). The BIS department of DOC has the jurisdiction to control dual-use exports that have an influence on the national security of the countries. However, according to Orr and Lee (2009) not all, or even a large percentage, of biological productions and processing technologies, are regarded dual-use and mentioned on the Commerce Control List (CCL). Researchers/ innovators and end-users are a different level of intention for dual-use items. While researchers/ innovators may intend a purpose and have no idea that a user might convert the innovation or research for other purposes, mainly destructive and criminal, and in the opposite, researchers may have no specific end-use of the item in mind (Williams-Jones, Olivier, \& Smith, 2014).

The moral codes of dual-use diffusion are vital as life researchers might be considered to be responsible for what they spread in terms of possible detrimental misuses, and this is why researchers would need guidance to be able to take such responsibility. The integration perspectives of dual-use dissemination would lead to a critical contribution to ethical literature in the life sciences field. Based on Kuhlau et al. (2013), three perspectives could be included in such moral codes:

- Dual-use awareness, able to recognize the dual-use dilemma;

- Precaution, able to be reflective and having cautious behavior in circumstances where releasing of knowledge may cause serious risks of detrimental results;

- Affirming conflicting values, prompting an identification that potential harm in specific research circumstances may outweigh expected benefits.

According to the mentioned context, SMEs are faced with the risk of dual-use punishments. As result, they may be fined or sanctioned by different organizations. That is why they have not only followed the regulations for the dual-use items precisely but also it is better for them not to enter even into the negotiation with suspicious parties. In this condition, SMEs can have a safe trading activity.

\subsection{Money Laundering}

Money laundering is one of the most happening international violations in the world which is a crime, legitimized by the fact that whoever launder money is looking for a way to justify their illegitimate profits which is collected through illegal activities and let offenders use the earnings of their crime (Baldwin, 2003). The main purpose of money laundering is to justify earnings originating from illegal endeavors, businesses or resources. Transforming the form of the money to mask of its origin is the bottom line of money laundering which, eventually, undermines economies and destabilize governmental administrative systems (Yang, 2002). As consequences of money laundering, financial markets become corrupted and the public's respect and trust to the international financial system are ruined and, eventually, the rate of growth of the global economy is declined due to the increase of risk in financial markets (Omar, Johari, \& Arshad, 2014).

Money laundering tries to distribute dirty money in various places around the world on the basis of running away from national or transnational controls, in that the suspicious money transfers to nations with less strict controls. In this regard, internationalization has increased the money launderers' capability to get in touch, letting them spreading transactions among more jurisdictions, thus growth in the number of legal challenges which might prevent the investigations or make gaps or obstacles in the investigation process. Parallel, or underground, banking or financial systems are other variables which also attracted the concerns of law enforcement and regulatory organizations (Buchanan, 2004).

As Buchanan (2004) reported, money laundering includes 3 processes: 


\subsubsection{Placement}

The first initial stage is placement (Schneider \& Windischbauer, 2008). Placement is carried out by changing the mass cash obtained from criminal efforts into a less suspicious and more portable form by putting those earnings into the mainstream financial system. The objective of placement is to prevent of being identified by the jurisdiction and eliminate the cash as far as possible from the original source of illegal proceeds. In the stage of placement, the mechanism of laundering is at its most vulnerable since most criminal activities create a massive amount of cash profits, which is arduous to disguise (Buchanan, 2004).

Consequently, the launderer needs to find a way to transform the bulk cash into a more reasonable and manageable form for circulation into the legal financial system. Such solutions could incorporate leveraging front corporations to transfer cash or check cashing businesses to convert cash to negotiable instruments such as money orders, cashier's checks, and traveler's checks (Buchanan, 2004).

\subsubsection{Layering}

By virtue of the so called layering, criminals effort to hide the source of illegal proceeds through a massive amount of transactions by circulating around black money (Schneider and Windischbauer 2008). Layering is considered of creating a network of financial transactions that in terms of volume, complexity, and frequency, complexity and volume mostly are similar to legal financial activity. By dint of the serial transactions and parallel networks, it becomes increasingly hard to reconstruct a paper trail. In the layering process, offshore financial centers perform a crucial function. In this approach, launderers try to conceal real origins of funds by performing wire transfer into a financial or banking system through offshore accounts (Buchanan, 2004).

\subsubsection{Integration}

The last part in process of money laundering is called integration. Integration incorporates rearranging the cleansed or washed funds with formal and legal economic activity (Buchanan, 2004). In the integration stage, infiltration of transformed capital into the formal financial system by means of monetary investments (specific deposits, stocks) or property (direct investment in real estates and companies) is primarily completed in economies promising extraordinary short odds (Schneider \& Windischbauer, 2008). Many of financial instruments including guarantees, bills of lading, bonds, letters of credit and bank notes are used for integration the laundered money (Buchanan, 2004).

Recognition of laundered money mainly takes place both at the preliminary step of the entrance of the money into the economic system and also in layering and integration processes of money laundering because infiltrated money is recognizable by an administrative paper trail. However, the reconstruction of these money trails can be acquired with the assistance of different approaches of cash flow analysis (Schneider and Windischbauer 2008). Thus, SMEs have to be transparent in their financial activities and frequently check their transactions for the sake of not falling in money laundering crimes. This process would be complex take the time, but it is urgent to keep SMEs alive for their activities.

However, failure to comply with each mentioned risks will face the organization with fines and punishments. Although there is not any specific punishment for this violations, the best example would be referring to the history. As the blind spot in this field, there is currently no specific international standards concerning consequences for export control violations. Nevertheless, there are some ambiguous requirements accessible in United Nations Security Council (UN-SC) resolutions and also in the international treaties of nuclear, chemical and biological weapons. Moreover, governments, separately, have considered an extensive range of administrative and criminal penalties for arms and dual-use violations (Bauer, 2014).

\section{Conclusion}

It is understood, SMEs have a critical role for survival and economic growth of many countries around the world (Spicer and Sadler-Smith 2006; Ueasangkomsate 2015). This paper has sought to investigate export compliance as an important subject for SMEs in the world of trade, and to create a framework to control and mitigate risks of export compliance.

In this regard, to have a safe export operation, organizations need to comply with the regulation about export compliance. Then, International Traffic in Arms Regulations (ITAR) issued by the US Department of State (DOS) and administered by the Office of Defense Trade Control, Export Administration Regulations (EAR) issued US Bureau of Industry \& Security (BIS), and the Office of Foreign Assets Control Regulations (OFAC) issued by the Department of Treasury's (DOT) office not only provides a comprehensive information about export compliance and control but also warn them about the consequences of disobeying from the regulations. European Institute for Export Compliance (EIFEC) is also another organization which aimed to facilitate 
exporting in terms of export compliance violations.

After defining concepts and issuing organizations, paper built a framework for managing risks related to export compliance. In order to mitigate and control risks resulting in sanctions and punishments, organizations need a framework to find their way. First, the framework identifies beneficiaries, and then it determines to constitute risks related to export compliance. Money laundering or "dirty money" (Fan, Lin, \& Camera, 2001) is considered as the first violation. Placement, layering, and integration are elements of the process of this violation that can result in punishments like imprisonment or monetary penalties. In the other side, dual-use items, products and technologies are normally used for civilian but which may have military applications (EC, 2016), are another violation that will cause sanctions and punishments for organizations. Finally, consequences including punishments and sanctions for non-complying with regulations are presented.

The development and adoption of EIFEC export compliance standards have influenced the governments to consider it not only as an instrument for major enterprises but as a management instrument easy deployable and flexible for being safely active in international markets. However, proportionate to the dimensional and operational complexity of organizations, an instrument can be and applied even by the smallest organization. Nevertheless, export compliance is an emerging issue that concerns any ventures in any nation. Non-compliance with international regulations face enterprises with trouble consequences that may jeopardize their future activity and existence.

\section{References}

Acs, Z., Léo-Paul, D., \& Marian, V. J.. (2003). Toward New Horizons: The Internationalisation of $\begin{array}{llll}\text { Entrepreneurship. Journal of International Entrepreneurship, } & \text { 1, 5-12. }\end{array}$ https://doi.org/10.1023/A:1023257414794.

Avellanet, J. (2008). Export Compliance for Life Sciences. Journal of Commercial Biotechnology, 14(2), 103-105. https://doi.org/ https://doi.org/10.1057/jcb.2008.4.

Baldwin, G. (2003). The New Face of Money Laundering. Journal of Investment Compliance, 4(1), 38-41. https://doi.org/10.1108/15285810310812997.

Bauer, S. (2014). Penalties for Export Control Offences for Dual-Use and Export Control Law : A Comparative Overview of Six Countries. Stockholm International Peace Research Institute-SIPRI.

Biancone, P. P., \& Vahid, J. S. (2016). Risk Management in Export Compliance: Concepts, Procedures, and Solutions. In V. Cantino, P. De Vincentiis, and G Racca, Risk Management: Perspectives and Open Issues. A Multi-Disciplinary Approach (pp. 47-62). McGraw-Hill Education, London, UK. http://www.ateneonline.it/cantino/ebook/

BIS. (2011). Export Management and Compliance Division Compliance Guidelines: How To Develop an Effective Export Management and Compliance," no. June. www.bis.doc.gov.

Blount, P. J. (2007). The ITAR Treaty and Its Implications for U.S. Space Exploration Policy and the Commercial Space Industry. Journal of Air Law and Commerce, 73, 705-723.

Buchanan, Bonnie. (2004). Money Laundering-A Global Obstacle. Research in International Business and Finance, 18(1), 115-127. https://doi.org/10.1016/j.ribaf.2004.02.001

Dana, L. P., \& Richard, W. W. (2009). International Entrepreneurship: Research Priorities for the Future. International Journal of Globalisation and Small Business, 3(1), 90-134. https://doi.org/10.1504/IJGSB.2009.021572

Dikova, D., Andreja, J., Anže, B., \& Aljaž, K. (2016). What Is Beneficial for First-Time SME-Exporters from a Transition Economy: A Diversified or a Focused Export-Strategy? Journal of World Business, 51(2), 185-199. https://doi.org/10.1016/j.jwb.2015.05.001

EC. (2016). Dual Use-Trade-European Commission. Retrieved from http://ec.europa.eu/trade/import-and-export-rules/export-from-eu/dual-use-controls/index_en.htm

EIFEC. (2017). European Code for Export Compliance EU-CEC. Retrieved from http://www.eifec.eu/docs/eu_cec.pdf

Etemad, H., Richard, W. W., \& Léo-Paul, D. (2001). Symbiotic International Business Networks: Collaboration between Small and Large Firms. Thunderbird International Business Review, 43(4), 481-499. Retrieved from http://onlinelibrary.wiley.com/doi/10.1002/tie.1009/abstract

Fan, A., Bing, L., \& Gabriele, C. (2001). Dirty Money. Journal of Monetary Economics, 47(2), 377-415. 
Fernández, Z., \& María, J. N. (2005). Internationalization Strategy of Small and Medium-Sized Family Businesses: Some Influential Factors. Family Business Review, 18(1), 77-89. https://doi.org/10.1111/j.1741-6248.2005.00031.x

Fusco, J. (2015). "Export Compliance Manual. AstroNova. Retrieved from https://www.astro-medinc.com/Export_Compliance_Manual.pdf

IIEI. (2016). The International Import-Export Institute. Retrieved from http://usexportcompliance.com/regulations/.

Jafari Sadeghi, V., Arash, J., \& Mehdi, H. C. (2014). Organization's Conformity Assessment with Peter Senge's Learning Organization Principles in Municipality of Saveh: A Case Study. Journal of Business and Management 16(5), 51-58. Retrieved from http://www.iosrjournals.org/iosr-jbm.html

Jafari, S. V., \& Paolo, P. B. (2017). How Micro, Small and Medium-Sized Enterprises Are Driven Outward the Superior International Trade Performance? A Multidimensional Study on Italian Food Sector. Reaserch in Business and Finance. http://dx.doi.org/10.1016/j.ribaf.2017.07.136

Khattak, J. K., Arslan, M., \& Umair, M. (2011). SMEs' Export Problems in Pakistan. E3Journals.Org 2(5), 192-199. Retrieved from http://www.e3journals.org/cms/articles/1330778191_Jamshed et al.pdf

Lehmann, P. R., Chur, H. T. W., Christian, H., \& Chur, H. T. W. (2013). Managing Export Risks. Export Risk Management Guidelines. Retrieved from http://www.s-ge.com/sites/default/.../Exportrisikomanagement_SGE_en.pdf

Leonidou, L. C. (2004). An Analysis of the Barriers Hindering Small Business Export Development." Journal of Small Business Management, 42(3), 279-302. https://doi.org/10.1111/j.1540-627X.2004.00112.x

Maignan, I., \& Bryan, A. L. (1997). Entry Mode Decisions: The Role of Managers' Mental Models." Journal of Global Marketing, 10(4), 7-22. https://doi.org/10.1300/J042v10n04

Majocchi, A., Emanuele, B., \& Ulrike, M. (2005). Firm Size, Business Experience and Export Intensity in SMEs: A Longitudinal Approach to Complex Relationships. International Business Review, 14(6), 719-738. https://doi.org/10.1016/j.ibusrev.2005.07.004

Masero, A. (2014). I Came, ITAR, I Conquered: The International Traffic in Arms Regulations, 3D-Printed Firearms, and the First Amendment. Boston CollegeLaw Review, 55, 1291-1328. https://doi.org/10.1525/sp.2007.54.1.23

Neupert, K. E., Christopher, B. C., \& Thi, T. L. D.. (2006). SME Exporting Challenges in Transitional and Developed Economies. Journal of Small Business and Enterprise Development, 13(4), 535-545. https://doi.org/10.1108/14626000610705732

OECD. (2008). Removing Barriers to SME Access to International Markets. OECD Publishing.

Ojasalo, J. (2009). A Model of Risk Management in Globalizing Companies. The Business Review, 13(1), 200-209.

Omar, N., Zulaikha, A. J., \& Roshayani, A. (2014). Money Laundering - FATF Special Recommendation VIII: A Review of Evaluation Reports. Procedia - Social and Behavioral Sciences, 145. 211-225. https://doi.org/10.1016/j.sbspro.2014.06.029

Orr, K., \& Betty, L. (2009). Demystifying Department of Commerce Export Controls for the Biosafety Professional Guidance for Evaluating Efficacy of Clostridium Difficile Spores. Applied Biosafety, 14(2).

Samson, V. (2015). Workshop Review: Export Controls of Space Systems. Astropolitics, 13(2-3), 118-122. https://doi.org/10.1080/14777622.2015.1083793

Saunders, K. M. (1999). The Regulation of Internet Encryption Technologies: Separating the Wheat from the Chaff. The John Marshall Journal of Information Technology \& Privacy Law, 17(3), 945-960.

Schneider, F., \& Ursula, W. (2008). Money Laundering: Some Facts. European Journal of Law and Economics, 26(3), 387-404. https://doi.org/10.1007/s10657-008-9070-x

Spicer, D. P., \& Eugene, Sadler-Smith. (2006). Organizational Learning in Smaller Manufacturing Firms." International Small Business Journal, 24(2), 133-158. https://doi.org/10.1177/0266242606061836

Thun, J. H., \& Hoenig, D. (2011). An Empirical Analysis of Supply Chain Risk Management in the German Automotive Industry. International Journal of Production Economics, 131(1), 242-249. https://doi.org/10.1016/j.ijpe.2009.10.010 
Troxel, J. M. (2005). Office of Foreign Assets Control Regulations: Making Attorneys Choose Between Compliance and the Attorney-Client Relationship. The Review of Litigation, 24(3), 637-667. https://doi.org/10.1525/sp.2007.54.1.23

Ueasangkomsate, P. (2015). Adoption E-Commerce for Export Market of Small and Medium Enterprises in Thailand. Procedia-Social and Behavioral Sciences, 207, 111-120. https://doi.org/10.1016/j.sbspro.2015.10.158

Williams-Jones, B., Catherine, O., \& Elise, S. (2014). Governing 'Dual-Use' Research in Canada: A Policy Review. Science and Public Policy, 41(1), 76-93. https://doi.org/10.1093/scipol/sct038

Yang, S. (2002). Money Laundering in China: A Policy Analysis.” Journal of Contemporary Criminal Justice, 18(4), 370-380. https://doi.org/10.1177/104398602237683

Zehir, C., Mahmut, K., \& Hacer, Y. (2015). The Mediating Role of Innovation Capability on Market Orientation and Export Performance: An Implementation on SMEs in Turkey. 11th International Strategic Management Conference, 700-708. https://doi.org/10.1016/j.sbspro.2015.10.141

Zou, S. M., \& Simona, S. (1998). The Determinants of Export Performance: A Review of the Empirical Literature between 1987 and 1997. International Marketing Review, 15(5), 333-356. https://doi.org/10.1108/02651339810236290

\section{Copyrights}

Copyright for this article is retained by the author(s), with first publication rights granted to the journal.

This is an open-access article distributed under the terms and conditions of the Creative Commons Attribution license (http://creativecommons.org/licenses/by/4.0/). 